\title{
12. CHEMICAL COMPOSITION OF SEDIMENTS FROM SITES 506, 507, 508, AND 509, LEG 70, DEEP SEA DRILLING PROJECT ${ }^{1}$
}

\author{
S. A. Moorby and D. S. Cronan, Applied Geochemistry Research Group, Geology Department, Imperial College, \\ London, S.W.7, United Kingdom
}

\section{INTRODUCTION}

Since its discovery in 1974 (Klitgord and Mudie, 1974), the Galapagos mounds hydrothermal field has received much attention. Sediment samples were taken during Leg 54 of the Deep Sea Drilling Project (DSDP) and by other expeditions to the area (e.g., Corliss et al., 1978). While a hydrothermal origin for the mounds sediments has been generally accepted, several different theories of origin for the mounds themselves have been proposed (e.g., Corliss et al., 1978; Natland et al., 1979; Williams et al., 1979).

One of the aims of DSDP Leg 70 was to return to the mounds field and, using the new hydraulic piston corer described elsewhere in this volume, to obtain more complete recovery of mounds sediments than had previously been possible. It was our hope that this would help in our understanding of the nature and origin of these deposits. In this chapter, we describe the results of chemical analysis of over 250 sediment samples taken during the course of Leg 70 .

\section{SAMPLES}

Samples were taken from every hole that was piston cored at Sites 506, 507, 508, and 509. A total of more than 250 samples were analyzed-these having been selected at varying intervals in the cores, depending on the lithological changes seen visually and by smear slide examination. The major sediment types recognized, described in detail in the site chapters, are in summary as follows:

\section{Pelagic Ooze}

A siliceous foraminifer-nannofossil ooze occurs in every hole and is the typical pelagic sediment in this area. A decrease in biogenic silica content to almost zero with increasing depth is typically seen in all holes on and near the mounds themselves. At all holes the surface pelagic sediment differs significantly from that at depth and is therefore discussed separately.

\section{Hydrothermal Sediment}

Two major types of hydrothermal deposits were recognized: Mn-oxide-rich sediment and nontronite.

\footnotetext{
${ }^{1}$ Honnorez, J., Von Herzen, R. P., et al., Init. Repts. DSDP, 70: Washington (U.S. Govt. Printing Office).
}

The first type, Mn-oxide-rich sediment, is always the uppermost hydrothermal sediment and consists of two subtypes:

1) Hard fragments of Mn-oxide crust. This was encountered in all the mounds holes (i.e., Holes 506, 506C, 507D, and 509B) although it was only comparatively abundant in Hole 509B and, because of its nature, was highly disturbed by the piston-coring operation.

2) Mn-oxide rich mud. This sediment type consists essentially of "normal" pelagic sediment containing abundant, finely disseminated Mn oxides. It was encountered only at Hole 509B, where it occurred above the Mn-oxide crusts.

The predominant component of the second major type of hydrothermal deposit, nontronite, which was recovered from all the mounds holes, is a green mineral of the smectite group. Two subtypes of this sediment were also recognized:

1) Dark green coarsely granular material.

2) Paler green, nongranular, or "compact," transitional sediment.

The latter material typically occurs between normal pelagic sediments and granular nontronite, both above and below the nontronite, and is regarded as being transitional between the two sediment types.

\section{ANALYTICAL METHODS}

After drying and crushing, the samples were digested in a mixture of hydrofluoric, nitric, and perchloric acids. Final solutions were made up in $1 M \mathrm{HCl}$ and sprayed on an ARL 34000 inductively coupled argon plasma emission spectrograph. Simultaneous determination of $\mathrm{K}, \mathrm{Mg}, \mathrm{Ca}, \mathrm{Al}, \mathrm{Mn}, \mathrm{Fe}, \mathrm{Li}, \mathrm{Be}, \mathrm{Cd}, \mathrm{Sr}, \mathrm{Ti}, \mathrm{V}, \mathrm{Cr}, \mathrm{Co}, \mathrm{Ni}, \mathrm{Cu}, \mathrm{Zn}, \mathrm{Pb}$, Mo, and $\mathrm{P}$ was made on each sample using a program developed within the Applied Geochemistry Research Group, incorporating drift and blank correction. Silica was determined by atomic absorption spectrophotometry after a separate digestion in hydrofluoric and hydrochloric acids in sealed containers. Accuracy and precision were checked using in-house and international reference materials and duplicates. Details are summarized in Table 1.

\section{ANALYTICAL RESULTS}

The analytical results are summarized in Table 2 . Overall, the data compare well with other published data for Galapagos mounds sediments (e.g., Dymond et al., 1980; Hoffert et al., 1980; Schrader et al., 1980a). Direct comparison is difficult in many cases, however, because material collected on Leg 54 (as a result of extensive drilling disturbance) was often a mixture of the sediment types described above. For example, on Leg 70 no evidence was found of any of the mixed $\mathrm{Fe}$ - and $\mathrm{Mn}$ - 
Table 1. Precision and accuracy of chemical analysis.

\begin{tabular}{|c|c|c|c|c|c|c|c|}
\hline \multirow[b]{2}{*}{ Element } & \multirow{2}{*}{$\begin{array}{l}\text { Replicate } \\
\text { Sample } \\
\text { Precision }\end{array}$} & \multicolumn{2}{|c|}{$\begin{array}{l}\text { Standard } \\
\text { SO-3 }\end{array}$} & \multicolumn{2}{|c|}{$\begin{array}{l}\text { Red Clay } \\
\text { Standard }\end{array}$} & \multicolumn{2}{|c|}{$\begin{array}{c}\text { Mn-nodule } \\
\text { Standard } \\
\text { Mangenknollen- } \\
\text { probe-4 }\end{array}$} \\
\hline & & Accepted & Found & Accepted & Found & Accepted & Found \\
\hline \multicolumn{8}{|c|}{$(\%)$} \\
\hline K & $\pm 10 \%$ & 1.2 & 1.6 & - & - & - & - \\
\hline $\mathrm{Mg}_{\mathrm{g}}$ & $\pm 3 \%$ & 5.1 & 4.6 & 1.9 & 1.8 & - & - \\
\hline $\mathrm{Ca}$ & $\pm 5 \%$ & 14.8 & 14.2 & 1.47 & 1.4 & 1.7 & 1.7 \\
\hline Al & $\pm 8 \%$ & 3.0 & 2.8 & 9.5 & 9.1 & 2.8 & $\cdot 2.0$ \\
\hline $\mathrm{Mn}$ & $\pm 5 \%$ & 0.052 & 0.049 & 0.45 & 0.42 & 31.8 & 31.4 \\
\hline $\mathrm{Fe}$ & $\pm 5 \%$ & 1.5 & 1.34 & 5.6 & 5.8 & 4.6 & 4.1 \\
\hline $\mathrm{Li}$ & $\pm 10 \%$ & - & - & 66 & 64 & - & - \\
\hline $\mathrm{Be}$ & $\pm 6 \%$ & - & - & - & - & - & - \\
\hline Cd & $\pm 8 \%$ & - & - & - & - & - & - \\
\hline $\mathrm{Sr}$ & $\pm 7 \%$ & 217 & 205 & - & - & - & - \\
\hline $\mathrm{P}$ & $\pm 6 \%$ & 480 & 530 & - & - & - & - \\
\hline $\mathrm{Ti}$ & $\pm 6 \%$ & 1900 & 1800 & 4900 & 4400 & 3000 & 2800 \\
\hline V & $\pm 5 \%$ & 44 & 51 & - & - & - & - \\
\hline $\mathrm{Cr}$ & $\pm 20 \%$ & 26 & 24 & 100 & 104 & 20 & 30 \\
\hline Co & $\pm 5 \%$ & 12 & 9 & 65 & 62 & 1700 & 1560 \\
\hline $\mathrm{Ni}$ & $\pm 8 \%$ & 16 & 13 & 120 & 110 & - & - \\
\hline $\mathrm{Cu}$ & $\pm 6 \%$ & 17 & 16 & 100 & 103 & 15000 & 15000 \\
\hline $\mathrm{Zn}$ & $\pm 3 \%$ & 52 & 47 & 130 & 147 & 1580 & 1540 \\
\hline $\mathrm{Pb}$ & $\pm 8 \%$ & 14 & 20 & - & - & 330 & 350 \\
\hline Mo & $\pm 12 \%$ & - & - & - & - & - & - \\
\hline
\end{tabular}

rich sediments reported extensively on Leg 54 (see, for example, Hekinian et al., 1978; Schrader et al., 1980b).

The average compositions of each major sediment type (pelagic ooze, Mn-oxide-rich sediment, nontronite, transitional sediment) show no major differences between different holes at the same site or even between sites. The nontronite sediments in particular show very constant composition throughout the mounds holes. The chemistry of each type will be described separately.

\section{Pelagic Sediments}

\section{Surface Pelagic Sediment}

At all holes, a surface pelagic-sediment layer occurs up to $30 \mathrm{~cm}$ thick, which is brown in color in contrast to the grey-green of the underlying pelagic sediment (see site summaries). This layer represents the uppermost oxidized layer of the sediments in which the $\mathrm{Mn}$ is present predominantly as the dioxide. It is a typical feature of the sediments in the region (Bonatti et al., 1971) and was encountered in Leg 54 sites in the mounds area (Dymond et al., 1980). These surface sediments are enriched in $\mathrm{Mn}, \mathrm{Ni}, \mathrm{Cu}, \mathrm{Zn}$, and $\mathrm{P}$ compared to the underlying pelagic sediment (see Table 2). The Mn enrichment results from its diagenetic remobilization and reprecipitation near the surface (Lynn and Bonatti, 1965), and selective chemical leaching of the samples (Varnavas et al., this volume) indicates that the other enriched elements are associated with the Mn phase. The surface pelagic sediment is similar in composition in most mounds holes, off-mounds holes, and nonmounds holes, but small variations do occur.

\section{Basal Pelagic Sediment}

Samples immediately overlying basement were analyzed from nine holes. Their average composition is given in Table 3 and compared with that of basal sediments from several areas on the East Pacific Rise (EPR) (Dymond et al., 1973; Boström et al., 1976; Cronan, 1976; Heath and Dymond, 1977). While the nine samples do show some variation, there is no significant difference in the composition of basal sediments from the different hole types (i.e., mounds, off-mounds, nonmounds). Three holes $(506,507 \mathrm{~F}$, and 509B) show some basal enrichment of $\mathrm{Fe}$, but even in these samples $\mathrm{Fe}, \mathrm{Mn}, \mathrm{Cu}$, $\mathrm{Ni}$, and $\mathrm{Zn}$ are much lower, and $\mathrm{Al}$ and $\mathrm{Ti}$ much higher, than typical values for EPR basal metalliferous sediments (Table 3). The metal ratios in these sediments (Fig. 1) also show that they are more closely associated with pelagic sediments and biogenic material than EPR basal-metalliferous sediments. The basal sediments in the mounds hydrothermal field, therefore, show little or

Table 2. Average bulk-chemical composition of the sediment types recognized on Leg 70.

\begin{tabular}{|c|c|c|c|c|c|c|c|}
\hline Element & $\begin{array}{l}\text { Pelagic } \\
\text { Sediments }\end{array}$ & $\begin{array}{l}\text { Surface } \\
\text { Sediment }\end{array}$ & $\begin{array}{c}\text { Basal } \\
\text { Sediment }\end{array}$ & Nontronites & $\begin{array}{l}\text { Transitional } \\
\text { Sediment }\end{array}$ & $\begin{array}{l}\text { Mn-oxide } \\
\text { Rich } \\
\text { Sediment }\end{array}$ & Mottles \\
\hline \multicolumn{8}{|c|}{$(\%)$} \\
\hline K & $0.26(0.79)$ & 0.25 & 0.22 & 1.5 & 1.1 & 0.54 & 0.47 \\
\hline $\mathrm{Mg}_{8}$ & $0.70(2.1)$ & 0.65 & 0.77 & 2.2 & 2.1 & 1.5 & 1.0 \\
\hline $\mathrm{Ca}$ & 26.8 & 23.8 & 30.7 & 0.40 & 5.4 & 4.0 & 24.7 \\
\hline $\mathrm{Al}$ & $1.2(3.7)$ & 1.2 & 1.16 & 0.28 & 2.2 & 0.85 & 1.1 \\
\hline $\mathrm{SiO}_{2}$ & $14.8(44.8)$ & 15.2 & 10.0 & 43.5 & 35.9 & 8.6 & 0.0 \\
\hline $\mathrm{Mn}^{2}$ & $0.26(0.79)$ & 2.1 & 0.19 & 0.11 & 0.19 & 33.3 & 0.23 \\
\hline $\mathrm{Fe}$ & $1.25(3.8)$ & 1.26 & 1.48 & 20.2 & 9.96 & 1.1 & 3.8 \\
\hline \multicolumn{8}{|c|}{ (ppm) } \\
\hline $\mathrm{Li}$ & $8.3(25)$ & 5.1 & 7.2 & 8.4 & 21 & 65 & 8.7 \\
\hline $\mathrm{Be}$ & $0.3(0.9)$ & 0.3 & 0.3 & 0.27 & 0.5 & 0.25 & 0.34 \\
\hline $\mathrm{Cd}$ & $1.7(5.2)$ & 1.6 & 1.6 & 4.2 & 2.7 & 1.7 & - \\
\hline $\mathrm{Sr}$ & $960(2900)$ & 1050 & 1160 & 47 & 310 & 600 & 780 \\
\hline $\mathrm{Ti}$ & $570(1730)$ & $\$ 20$ & 715 & 117 & 990 & 325 & 495 \\
\hline v & $67(200)$ & 50 & 58 & 17 & 95 & 96 & 42 \\
\hline $\mathrm{Cr}$ & $30(91)$ & 30 & 26 & 31 & 47 & 37 & 32 \\
\hline Co & 9 (27) & 12 & 12 & 3 & 10 & 14 & 6 \\
\hline $\mathrm{Ni}$ & $85(260)$ & 161 & 63 & 17 & 77 & 173 & 48 \\
\hline $\mathrm{Cu}$ & $84(255)$ & 102 & 58 & 21 & 118 & 94 & 58 \\
\hline $\mathrm{Zn}$ & $140(420)$ & 177 & 76 & 56 & 171 & 142 & 102 \\
\hline $\mathrm{Pb}$ & 17 (52) & 16 & 18 & 16 & 21 & 65 & 10 \\
\hline Mo & $1.5(4.5)$ & 1.3 & - & 4.9 & 3.9 & 390 & 1.5 \\
\hline P & 440 (1330) & 675 & 430 & 250 & 460 & 1130 & 360 \\
\hline \multicolumn{8}{|l|}{ No. of } \\
\hline Samples & 90 & 11 & 9 & 88 & 58 & 13 & 11 \\
\hline
\end{tabular}

Note: Figures in parentheses are data recalculated on a carbonate-free basis. 
Table 3. Comparison of composition of basal sediments recovered on Leg 70 with basal metalliferous sediments from the East Pacific Rise.

\begin{tabular}{|c|c|c|c|c|c|c|}
\hline \multirow[b]{2}{*}{ Element } & \multicolumn{2}{|c|}{ Basal Sediments } & \multirow{2}{*}{$\begin{array}{c}\text { Boström } \\
\text { et al. } \\
\text { (1976) }\end{array}$} & \multirow{2}{*}{$\begin{array}{l}\text { Heath and } \\
\text { Dymond } \\
\text { (1977) }\end{array}$} & \multirow{2}{*}{$\begin{array}{l}\text { Dymond } \\
\text { et al. } \\
\text { (1973) }\end{array}$} & \multirow[b]{2}{*}{$\begin{array}{l}\text { Cronan } \\
\text { (1976) }\end{array}$} \\
\hline & Uncorrected & $\begin{array}{c}\text { Carbonate- } \\
\text { Free Basis }\end{array}$ & & & & \\
\hline \multicolumn{7}{|c|}{$(\%)$} \\
\hline K & 0.22 & 0.91 & - & - & - & 1.2 \\
\hline $\mathrm{Mg}$ & 0.77 & 3.2 & - & - & 1.07 & 2.1 \\
\hline $\mathrm{Ca}$ & 30.7 & - & - & - & - & 1.5 \\
\hline $\mathrm{Al}$ & 1.2 & 4.8 & 1.6 & 0.26 & 3.2 & 2.7 \\
\hline $\mathrm{SiO}_{2}$ & 10.0 & 41.3 & - & 8.8 & 17.3 & 23.2 \\
\hline $\mathrm{Mn}^{2}$ & 0.19 & 0.8 & 7.6 & 12.4 & 4.9 & 6.2 \\
\hline $\mathrm{Fe}$ & 1.5 & 6.2 & 23.0 & 41.0 & 27.0 & 20.7 \\
\hline \multicolumn{7}{|c|}{ (ppm) } \\
\hline $\mathrm{Ti}$ & 715 & 2950 & 1500 & - & - & - \\
\hline$\ddot{v}$ & 58 & 240 & 700 & - & - & - \\
\hline $\mathrm{Cr}$ & 26 & 110 & 37 & - & - & - \\
\hline Co & 12 & 50 & 130 & - & - & - \\
\hline $\mathrm{Ni}$ & 63 & 260 & 640 & 640 & 470 & 470 \\
\hline $\mathrm{Cu}$ & 58 & 240 & 1200 & 1900 & 1200 & 8000 \\
\hline $\mathrm{Zn}$ & 76 & 310 & 750 & 410 & - & - \\
\hline $\mathrm{P}$ & 430 & 1800 & 1000 & - & - & - \\
\hline No. Analyzed & 9 & 9 & 35 & $\begin{array}{c}\text { Not } \\
\text { Known }\end{array}$ & 6 & 25 \\
\hline $\begin{array}{l}\text { Corrected for } \\
\mathrm{CaCO}_{3} \\
\text { Content }\end{array}$ & No & Yes & Yes & Yes & No? & $\begin{array}{c}\text { No } \\
\text { (non- } \\
\text { carbonate) }\end{array}$ \\
\hline
\end{tabular}

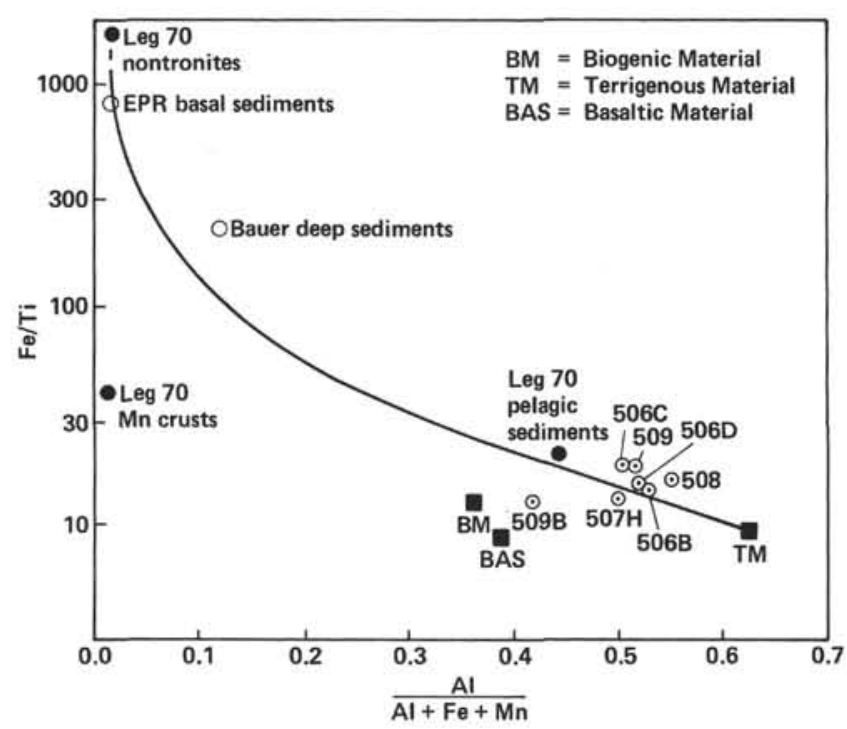

Figure 1. Metal ratios in Leg 70 basal and other sediments (after Boström et al., 1976; other data from Bischoff and Rosenbauer, 1977).

no affinity with basal sediments recovered elsewhere on the East Pacific Rise. Dymond and his colleagues (1980) analyzed basal sediments from holes on Leg 54 and found some similarities between this material and basal sediment from $6^{\circ} \mathrm{S}$ on the East Pacific Rise. They concluded that there was evidence for the formation of metal-enriched basal sediments in the mounds area. Their conclusion, however, was based primarily on the similarity of the $\mathrm{Fe} / \mathrm{Mn}$ ratios of the two sample groups. In view of the contamination problems of Leg 54 samples, and the markedly different $\mathrm{Al}, \mathrm{Ti}, \mathrm{Mn}, \mathrm{Fe}, \mathrm{Ni}, \mathrm{Cu}$, and $\mathrm{Zn}$ contents of mounds sediments compared with typical metalliferous sediment, we do not believe that marked basal metal enrichment of the sediments occurs at any of the sites drilled in the mounds area. On the evidence of Figure 1, the composition of these sediments can in most cases be accounted for simply in terms of a mixture of biogenic, basaltic, and terrigenous material.

Another feature of the basal sediments is their low $\mathrm{Al} / \mathrm{Ti}$ ratio compared to the other sample groups analyzed (Table 6). This probably results from the common occurrence of basalt fragments in the sediment immediately above basement, these basalts being particularly Ti-rich (Hekinian et al., 1978; Mattey and Muir, 1980).

\section{Other Pelagic Sediments}

The pelagic sediments from all holes cored were mainly siliceous carbonate oozes. In surface and nearsurface sediments, the ratio of $\mathrm{SiO}_{2}$ to $\mathrm{CaCO}_{3}$ is about $1: 5$, but with increasing depth the biogenic-silica content falls to almost zero (see site chapters). The decrease is not gradual but seems to occur within a fairly narrow depth interval, which is at shallower depth in mounds holes than off-mounds and nonmounds holes (Honnorez, Von Herzen, et al., 1981). While dissolution of biogenic silica within the sediment column is a widespread phenomenon (Calvert, 1974; Chester and Aston, 1976), it is highly temperature dependent (Dapples, 1967). The variations seen may, therefore, result from different heat-flow characteristics at the different holes (see Honnorez, Von Herzen, et al., 1981). In order to facilitate comparison with data for Leg 54 sediments, the pelagic sediment data in Table 2 and elsewhere in this chapter have not been corrected for carbonate or biogenic silica content except where stated. On this basis, the data compare well with those for pelagic sediments recovered on Leg 54 (Dymond et al., 1980; Shrader et al., 1980a) and with other analyses of sediments from this area (Bonatti et al., 1971). While Mn shows some variation between holes there is generally very little variation in the average composition of this sediment type between holes, and there is no significant difference in the composition of pelagic sediments in mounds, off-mounds, or nonmounds holes.

\section{Hydrothermal Sediment}

\section{Mn-Oxide Crust}

Because of the fragmented nature of the Mn-oxide crusts and the nature of the piston-coring operation, doubt must be cast on the stratigraphic positions of some of the crusts analyzed. This applies to the two samples from Hole 507D (in Core 2, Section 1) and to Sample 509B-2-1, 98-100 cm. The average chemical composition of all crusts analyzed is given in Table 4, together with, for comparison, the composition of hydrothermal crusts from various localities analyzed by other workers. Some of the minor and trace metals show significant variations between holes; in particular $\mathrm{Li}$ is enriched and $\mathrm{Sr}$ depleted in Hole 507D samples, while Mo is enriched in Holes 506 and 507D. Some differences occur in the composition of crusts analyzed in this work compared with mounds crusts analyzed by Hekinian et al. (1978) and Schrader et al. (1980a). In particular $\mathrm{Mn}$ is slightly lower while $\mathrm{SiO}_{2}, \mathrm{Al}, \mathrm{Fe}$, and V 
Table 4. Comparison of bulk composition of Mn-oxide crusts and sediments from Leg 70 with other Mn-rich deposits.

\begin{tabular}{|c|c|c|c|c|c|c|c|c|c|c|c|c|c|c|c|c|c|c|}
\hline Samples & $\begin{array}{c}K \\
(\%)\end{array}$ & $\begin{array}{l}\mathrm{Mg} \\
(\%)\end{array}$ & $\begin{array}{c}\mathrm{Ca} \\
(\%)\end{array}$ & $\begin{array}{c}\mathrm{Al} \\
(\%)\end{array}$ & $\begin{array}{l}\mathrm{SiO}_{2} \\
(\%)\end{array}$ & $\begin{array}{l}\mathrm{Mn} \\
(\%)\end{array}$ & $\begin{array}{l}\mathrm{Fe} \\
(\%)\end{array}$ & $\underset{(\mathrm{ppm})}{\mathrm{Li}}$ & $\underset{(\mathrm{ppm})}{\mathrm{Sr}}$ & $\underset{(\mathrm{ppm})}{\mathrm{P}}$ & $\begin{array}{c}\mathrm{Ti} \\
(\mathrm{ppm})\end{array}$ & $\underset{(\mathrm{ppm})}{\mathrm{V}}$ & $\underset{\text { (ppm) }}{\text { Co }}$ & $\underset{(\mathrm{ppm})}{\mathrm{Ni}}$ & $\underset{(\mathrm{ppm})}{\mathrm{Cu}}$ & $\underset{(\mathrm{ppm})}{\mathrm{Zn}}$ & $\begin{array}{c}\mathrm{Pb} \\
(\mathrm{ppm})\end{array}$ & $\begin{array}{c}\text { Mo } \\
(\mathrm{ppm})\end{array}$ \\
\hline $\begin{array}{l}\text { Mn-Crusts } \\
\text { (Av. of 8) }\end{array}$ & 0.71 & 1.6 & 0.98 & 0.24 & $\begin{array}{c}3.1 \\
(\mathrm{n}=2)\end{array}$ & 47.0 & 0.66 & 100 & 660 & 1200 & 28 & 107 & 13 & 124 & 80 & 93 & 72 & 540 \\
\hline $\begin{array}{l}\text { Mounds Mn-Crust } \\
\text { (Schrader et al., 1980a) }\end{array}$ & 0.41 & 2.5 & 4.1 & 0.12 & 0.81 & 45.3 & 0.22 & - & 390 & - & 60 & 18 & 11 & 83 & 48 & 160 & - & - \\
\hline $\begin{array}{l}\text { Mounds Mn-Crust } \\
\text { (Hekinian et al., 1978) }\end{array}$ & 0.23 & 1.9 & 0.98 & 0.41 & 0.71 & 54.9 & 0.24 & - & - & - & - & - & - & - & - & - & - & - \\
\hline $\begin{array}{l}\text { Various Localities } \\
\text { (Toth, 1980) }\end{array}$ & - & - & - & 0.13 & 0.92 & 45.6 & 0.18 & - & - & - & - & - & 17 & 640 & 320 & 1030 & 10 & - \\
\hline $\begin{array}{l}\text { Hydrogenous Mn } \\
\text { Nodules, Pacific Ocean } \\
\text { (Cronan, 1975) }\end{array}$ & 0.75 & 1.7 & 2.0 & 3.1 & 17.8 & 19.8 & 12.0 & - & 850 & 2350 & 6700 & 530 & 3400 & 6300 & 3900 & 680 & 850 & 440 \\
\hline $\begin{array}{l}\text { Continental Borderland } \\
\text { Nodules (Cronan, 1972) }\end{array}$ & - & - & - & - & - & 34.0 & 1.6 & - & - & - & 600 & 310 & 75 & 970 & 650 & - & 60 & 720 \\
\hline
\end{tabular}

are all higher in our samples. This may be explained partly in terms of a greater admixture of diluting pelagic sediment in our samples, although the $\mathrm{Ca}$ content indicates that little, if any, carbonate material is incorporated. Levels of $\mathrm{Ni}, \mathrm{Cu}$, and $\mathrm{Zn}$ in the samples were generally less than $200 \mathrm{ppm}, \mathrm{Pb}$ less than $100 \mathrm{ppm}$, and Co less than $20 \mathrm{ppm}$. None of the crusts analyzed showed comparatively high $\mathrm{Ni}, \mathrm{Cu}$, and $\mathrm{Zn}$ values as did several analyzed by Corliss et al. (1978).

The low trace-element content of hydrothermally derived Mn-rich crusts has been regarded (Bonatti et al., 1972; Toth, 1979; and others) as evidence of their rapid accumulation and of a higher ratio of Mn to trace metals in hydrothermal solutions than in normal seawater. The comparatively high concentrations of some metals in hydrothermal crusts, however, have led to the suggestion that they either may be supplied to some extent by hydrothermal solutions (Zn, As, Hg: see Toth, 1980), or they may be incorporated by a mechanism other than surface adsorption (U: see Scott et al., 1974). Zinc, after Fe and $\mathrm{Mn}$, has been found to be the metal taken into solution in highest concentration by hydrothermal leaching (Seyfried and Bischoff, 1977); Toth (1980), therefore, used the $\mathrm{Co} / \mathrm{Zn}$ ratio as an indicator of the degree of hydrothermal, as opposed to hydrogenous, supply of trace metals to ferromanganese-oxide deposits. Using the same criterion the crusts analyzed in this study show evidence of a predominantly hydrothermal supply of metals. Data for $\mathrm{Li}$ in hydrogenous $\mathrm{Mn}$-oxides are lacking, but the comparatively high levels of this element in Leg 70 crusts may also indicate hydrothermal supply. The enrichment of Mo in the crusts is particularly striking: average values are as high as in the $\mathrm{Mn}$-, $\mathrm{Ni}-$, and $\mathrm{Cu}$-rich hydrogenous nodules of the northeast Pacific. The highest Mo values are similar to those in diagenetically Mnenriched nodules from the Mexican continental margin (Cronan, 1972), which otherwise show a very different chemical composition.

At none of the sites drilled was Mn-oxide crust present at the sediment-water interface, but there was always a certain thickness of typical pelagic ooze above the crusts, indicating that Mn-oxide deposition may not be occurring at the present time. However, we do not know where the various holes were located with respect to the active chimneys. At Hole 509B much of the sediment capping the Mn-oxide crust was markedly enriched in $\mathrm{Mn}$.

\section{Mn-Oxide-Rich Mud}

Both the physical appearance and smear-slide examination of the Mn-oxide-rich mud, which was found only at Hole 509B, showed it to consist essentially of typical pelagic ooze admixed with varying amounts of finely divided Mn oxides. The average composition of four samples of this mud is given in Table 4. Comparison of the data with those for the crusts and pelagic ooze (Table 2) shows that the mud is intermediate in composition between that of the crusts and the pelagic ooze, thereby confirming the visual observation that the material is a mixture of these two sediment types.

\section{Nontronite: Granular}

The granular dark green clay recovered from the mounds has been identified by previous workers as predominantly a nontronite (Corliss et al., 1978; Hekinian et al., 1978; Hoffert et al., 1980), and X-ray analysis of samples collected on Leg 70 confirmed this (Honnorez et al., this volume; Kurnosov et al., this volume). Compared with the carbonate-free fraction of the pelagic oozes, the nontronites are significantly depleted in $\mathrm{Ca}$, $\mathrm{Al}, \mathrm{Mn}, \mathrm{Li}, \mathrm{Be}, \mathrm{Sr}, \mathrm{Ti}, \mathrm{V}, \mathrm{Cr}, \mathrm{Co}, \mathrm{Ni}, \mathrm{Cu}, \mathrm{Zn}, \mathrm{Pb}$, and $\mathrm{P}$ and enriched in $\mathrm{K}$ and $\mathrm{Fe} ; \mathrm{Mg}, \mathrm{SiO}_{2}$, and $\mathrm{Mo}$ are neither enriched nor depleted. The generally low trace-metal content and lack of significant correlations of minor metals with $\mathrm{Fe}$ (Table 5) suggest that the nontronites are very pure precipitates and that trace elements are incorporated within impurities rather than within the nontronite itself. The elements $\mathrm{Ca}$ and $\mathrm{Al}$ also show little or no correlation with Fe. Donnelly (1980) has proposed that $\mathrm{K}$ and $\mathrm{Mg}$ are essential components of the nontronite structure and that their weak negative correlation with $\mathrm{Fe}$ and positive correlation with each other suggest that in pure nontronite these elements may indeed occupy definite crystallographic sites, which, however, may also be occupied by Fe. The positive correlation of $\mathrm{Fe}$ with $\mathrm{P}$ confirms the close association of $\mathrm{P}$ 
Table 5. Correlation coefficients for elements in Leg 70 nontronites.

\begin{tabular}{|c|c|c|c|c|c|c|c|c|c|c|c|c|c|c|c|c|}
\hline & $\mathrm{K}$ & $\mathrm{Mg}$ & $\mathrm{Ca}$ & Al & $\mathrm{Mn}$ & $\mathrm{Fe}$ & $\mathrm{Li}$ & Sr & $\mathrm{Ti}$ & $\mathrm{v}$ & Co & $\mathrm{Ni}$ & $\mathrm{Cu}$ & $\mathrm{Zn}$ & $\mathrm{Pb}$ & P \\
\hline $\mathrm{Mg}$ & 0.53 & & & & & & & & & & & & & & & \\
\hline $\mathrm{Ca}$ & & 0.28 & & & & & & & & & & & & & & \\
\hline $\begin{array}{l}\mathrm{Al} \\
\mathrm{Mn}\end{array}$ & & & & & & & & & & & & & & & & \\
\hline $\mathrm{Fe}$ & -0.26 & -0.25 & & & & & & & & & & & & & & \\
\hline $\mathrm{Li}$ & & 0.58 & 0.46 & & & & & & & & & & & & & \\
\hline $\mathrm{Sr}$ & & & 0.58 & & & & & & & & & & & & & \\
\hline $\mathrm{Ti}$ & & & & 0.93 & & & & & & & & & & & & \\
\hline v & & & & 0.70 & & & & & 0.72 & & & & & & & \\
\hline Co & & & & 0.39 & & & & & 0.39 & 0.43 & & & & & & \\
\hline $\mathrm{Ni}$ & & & & 0.51 & & & 0.32 & 0.33 & 0.51 & 0.79 & 0.58 & & & & & \\
\hline $\mathrm{Cu}$ & & & & 0.63 & & & & & 0.65 & 0.75 & 0.49 & 0.83 & & & & \\
\hline $\mathrm{Zn}$ & & & & & & & & & & & & 0.31 & & & & \\
\hline $\begin{array}{l}\mathrm{Pb} \\
\mathrm{Pb}\end{array}$ & & & & & & 0.66 & & & & & & & 0.42 & & & \\
\hline Mo & & & & & & 0.66 & & & & & & & & & & 0.51 \\
\hline
\end{tabular}

with hydrothermal Fe phases (Froelich et al., 1977) although its mechanism of incorporation into nontronite is not known. Of the other elements, $\mathrm{Ti}, \mathrm{V}, \mathrm{Ni}$, and $\mathrm{Cu}$ show significant correlations with each other and with $\mathrm{Al}$, suggesting their presence in included impurities rather than in the nontronite itself. The correlation between $\mathrm{Al}$ and $\mathrm{Ti}$ is particularly good (Fig. 2), and the $\mathrm{Al} / \mathrm{Ti}$ ratio is very similar to that in the pelagic oozes and other sample groups (Table 6). This suggests that little or no $\mathrm{Al}$ is actually incorporated within the nontronite structure. A major feature of the nontronites is their very constant composition both with depth within single holes and between holes.

Determination of the $\mathrm{Fe}^{3+} / \mathrm{Fe}^{2+}$ ratio was carried out on 15 nontronite samples. The results (Table 7) show that small variations in this ratio do occur. In particular it is interesting to note that the single brown sample (507D$2-1,66-68 \mathrm{~cm}$ ) had the highest $\mathrm{Fe}^{3+} / \mathrm{Fe}^{2+}$ ratio of any analyzed, while the most intensely green sample (506-3$2,6-8 \mathrm{~cm}$ ) had the lowest.

\section{Nontronite: Transitional Sediment}

The nongranular pale green sediment which typically occurs between pelagic ooze and granular nontronite

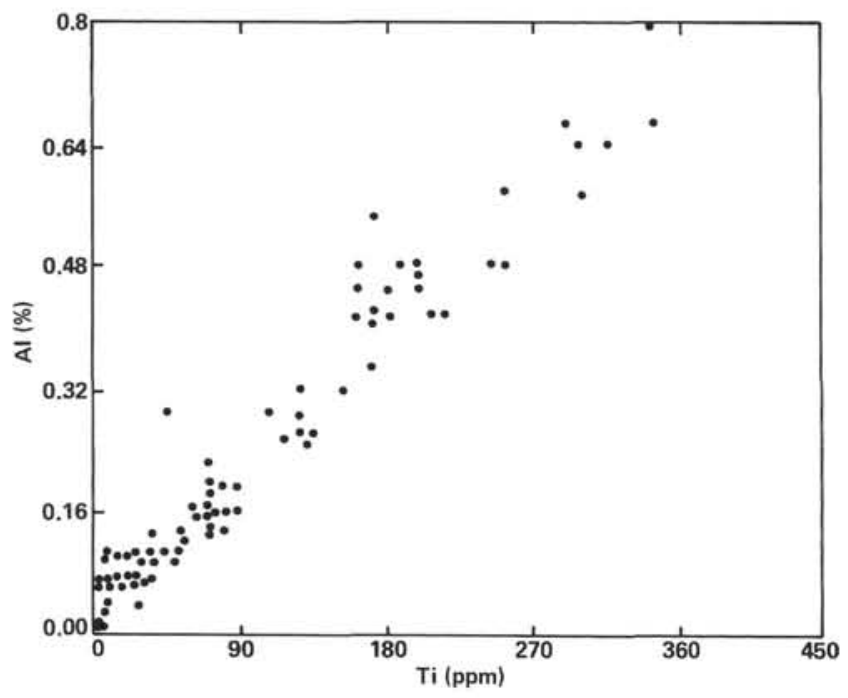

Figure 2. Scatter plot of $\mathrm{Al}$ vs. $\mathrm{Ti}$ in nontronites from all Leg 70 mounds holes. horizons in the mounds holes was not reported from Leg 54, almost certainly because of the extensive drilling disturbance resulting from rotary drilling. Because of its position between "pure" granular nontronite and "pure" pelagic ooze, the transitional material is of particular importance in interpreting the mechanism of formation of the hydrothermal sediments themselves. The average composition of transitional sediments at each mounds hole is given in Table 8. More variation occurs from hole to hole in this sediment type than in pelagic oozes and pure nontronites. The average composition of all transitional sediments recalculated on a carbonatefree basis is intermediate between that of pelagic oozes (on a carbonate-free basis) (Table 8) and pure nontronite (Table 2), suggesting that the transitional sediment is a mixture of these two sediment types. The holeto-hole variation in transitional sediment composition is probably largely the result of variations in the proportions of these two components.

Some horizons of pelagic ooze in mounds holes were characterized by green mottles (see site summaries). Several samples of this material were analyzed (Table 2). Their composition agrees with the notion that these mottles are areas of incipient transitional sediment formation.

\section{DISCUSSION}

The chemical data presented above enable us to address some of the problems associated with the hydrothermal mounds field. One of their most interesting features is that the surface pelagic sediment and much of the pelagic sediment at depth shows little or no evidence of the hydrothermal activity which has given rise to the mounds. The basal sediments in the mounds area show little evidence of the patterns of metal enrichment typical of basal sediment on the EPR flanks. However, if such sediments were at one time present in this area then the hydrothermal activity giving rise to the mounds has altered these sediments, perhaps by dissolving and remobilizing their initial hydrothermal component. The fact that normal pelagic ooze capped all the mounds that were cored suggests either that the mounds had not been active for some time, at least where drilled, or that nontronite formation is largely a subsurface process which does not affect the surface pelagic sediment. Two factors favor the latter theory. First, the presence of 
Table 6. $\mathrm{Al} / \mathrm{Ti}$ ratios in different sediment types at each site.

\begin{tabular}{|c|c|c|c|c|c|c|c|c|c|c|c|}
\hline \multirow{2}{*}{$\begin{array}{l}\text { Sediment } \\
\text { Type }\end{array}$} & \multicolumn{10}{|c|}{ Hole } & \multirow{2}{*}{$\begin{array}{l}\text { All Sites } \\
\text { Average }\end{array}$} \\
\hline & 506 & $506 \mathrm{~B}$ & $506 \mathrm{C}$ & $506 \mathrm{D}$ & 507D & $507 \mathrm{~F}$ & $507 \mathrm{H}$ & 508 & 509 & $509 \mathrm{~B}$ & \\
\hline Pelagic Ooze & 21 & 23 & 21 & 23 & 21 & 22 & 21 & 20 & 20 & 19 & 21 \\
\hline Surface Sediment & - & - & - & - & - & - & - & - & - & - & 23 \\
\hline Basal Sediment & - & - & - & - & - & - & - & - & - & - & 16 \\
\hline $\begin{array}{l}\text { Transitional } \\
\text { Sediment }\end{array}$ & 22 & - & 23 & - & 22 & 22 & - & - & - & 21 & 22 \\
\hline Nontronites & 22 & - & 28 & - & 21 & 21 & - & - & - & 30 & 24 \\
\hline Mottles & - & - & - & - & - & - & - & - & - & - & 22 \\
\hline Mn-Oxides & - & - & - & - & - & - & - & - & - & - & 26 \\
\hline
\end{tabular}

Table 7. $\mathrm{Fe}^{3+} / \mathrm{Fe}^{2+}$ ratios in selected nontronite samples.

\begin{tabular}{lcccc}
\hline $\begin{array}{c}\text { Sample } \\
\text { (interval in cm) }\end{array}$ & $\begin{array}{c}\mathrm{Fe} \text { Total } \\
(\%)\end{array}$ & $\begin{array}{c}\mathrm{Fe}^{2+} \\
(\%)\end{array}$ & $\mathrm{Fe}^{3+} / \mathrm{Fe}^{2+}$ & $\begin{array}{c}\mathrm{Fe}^{2+} \text { as \% } \\
\text { of Total Fe }\end{array}$ \\
\hline $506-2-2,147-149$ & 20.0 & 0.77 & 26 & 4 \\
$506-3-2,6-8$ & 18.6 & 1.68 & 11 & 9 \\
$506-3-3,60-62$ & 16.8 & 0.77 & 22 & 4.5 \\
$506 C-3-1,124-126$ & 20.0 & 0.84 & 24 & 4 \\
506C-4-1, 38-40 & 19.7 & 0.42 & 47 & 2 \\
506C-4-1, 127-129 & 20.2 & 0.70 & 29 & 3.5 \\
506D-2-3, 72-74 & 19.3 & 0.91 & 21 & 5 \\
507D-2-1, 66-68 & 21.5 & 0.21 & 102 & 1 \\
507D-5-1, 104-106 & 22.6 & 1.12 & 20 & 5 \\
507D-6-1, 80-82 & 16.6 & 1.14 & 15 & 7 \\
509B-3-2, 135-137 & 20.5 & 0.78 & 26 & 4 \\
509B-4-2, 51-53 & 17.4 & 0.85 & 20 & 5 \\
509B-4-3, 40-42 & 20.4 & 0.63 & 32 & 3 \\
509B-4-3, 88-90 & 17.0 & 0.60 & 28 & 3.5 \\
\hline
\end{tabular}

Table 8. Average composition of transitional sediment from each hole sampled.

\begin{tabular}{|c|c|c|c|c|c|c|c|}
\hline \multirow[b]{2}{*}{ Element } & \multicolumn{5}{|c|}{ Hole } & \multirow{2}{*}{$\begin{array}{c}\text { All Sites } \\
\text { (CFB) } \\
(n=58)\end{array}$} & \multirow{2}{*}{$\begin{array}{c}\text { Pelagic } \\
\text { Sediment } \\
\text { (CFB) } \\
(n=90)\end{array}$} \\
\hline & $\begin{array}{c}506 \\
(n=22)\end{array}$ & $\begin{array}{c}506 C \\
(n=8)\end{array}$ & $\begin{array}{c}507 \mathrm{D} \\
(n=14)\end{array}$ & $\begin{array}{c}507 \mathrm{~F} \\
(n=4)\end{array}$ & $\begin{array}{c}509 \mathrm{~B} \\
(n=10)\end{array}$ & & \\
\hline & \multicolumn{7}{|c|}{$(\%)$} \\
\hline K & 1.1 & 1.4 & 0.93 & 0.73 & 1.1 & 1.2 & 0.8 \\
\hline $\mathrm{Mg}_{8}$ & 2.0 & 2.2 & 2.0 & 2.3 & 2.1 & 2.4 & 2.1 \\
\hline $\mathrm{Ca}$ & 7.2 & 2.6 & 7.0 & 0.8 & 3.4 & 5.4 & 27 \\
\hline Al & 2.1 & 2.5 & 1.9 & 3.3 & 1.9 & 2.5 & 3.7 \\
\hline $\mathrm{SiO}_{2}$ & 33.7 & 37.1 & 37.9 & 37.8 & 35.7 & 41.0 & 44.9 \\
\hline $\mathrm{Mn}^{2}$ & 0.22 & 0.35 & 0.08 & 0.09 & 0.20 & 0.22 & 0.8 \\
\hline \multirow[t]{2}{*}{$\mathrm{Fe}$} & 9.4 & 10.0 & 9.7 & 9.7 & 11.8 & 11.4 & 3.8 \\
\hline & \multicolumn{7}{|c|}{ (ppm) } \\
\hline $\mathrm{Li}$ & 21 & 18 & 21 & 35 & 17 & 24 & 25 \\
\hline Sr & 400 & 360 & 160 & 133 & 380 & 350 & 2900 \\
\hline P & 470 & 470 & 410 & 620 & 430 & 530 & 1330 \\
\hline $\mathrm{Ti}$ & 970 & 1100 & 850 & 1500 & 910 & 1130 & 1730 \\
\hline v & 100 & 75 & 84 & 160 & 86 & 109 & 200 \\
\hline $\mathrm{Cr}$ & 43 & 53 & 47 & 56 & 45 & 54 & 91 \\
\hline Co & 11 & 11 & 8 & 12 & 7 & 11 & 27 \\
\hline $\mathrm{Ni}$ & 110 & 75 & 43 & 90 & 50 & 88 & 260 \\
\hline $\mathrm{Cu}$ & 150 & 120 & 93 & 130 & 84 & 135 & 254 \\
\hline $\mathrm{Zn}$ & 180 & 150 & 160 & 270 & 150 & 195 & 424 \\
\hline $\mathrm{Pb}$ & 21 & 33 & 14 & 24 & 17 & 24 & 52 \\
\hline
\end{tabular}

Note: $\mathrm{CFB}=$ carbonate-free basis; $n=$ no. of samples analyzed.

transitional sediment between pelagic ooze and granular nontronite horizons, both above and below the nontronite, strongly suggests that the nontronite has formed by the subsurface replacement of existing pelagic ooze. Second, the formation of nontronite, either by direct precipitation or by combination of previously precipitated ferric hydroxides with silica, requires conditions which are slightly reducing or at least are not oxidizing (Harder, 1976; Pedro et al., 1978). Formation of nontronite in the mounds, therefore, is likely to occur at depths at least lower than the uppermost oxidized layer of pelagic sediment. This evidence, then, strongly favors a subsurface replacement origin for the nontronite in the mounds, as suggested by Williams et al. (1979), rather than the nontronite being a flash deposit, as suggested by $\mathrm{Na}$ tland et al. (1979).

Although nontronite formation may proceed at depth, the formation of Mn-oxide crusts is only likely to occur at the sediment surface because of the need for oxidizing conditions to precipitate the Mn. Since all the Mn crusts found on Leg 70 were covered by varying thicknesses of pelagic ooze, it may be that the mounds that were cored had indeed not been active for some time, at least in the immediate vicinity cored. The Mn-rich sediment found at Hole 509B is an interesting feature because this hole contains much more Mn-oxide crust, and at a greater depth, than the other mounds holes. It may be that if Mn-oxide crusts, initially formed at the mounds surface, subsequently become buried to sufficient depth, then they may become reduced and remobilized back to the sediment-water interface where the process may be repeated. The Mn-rich mud above the Mn crusts at Hole 509B may therefore represent a stage in this process. Such a process could be important since $\mathrm{Fe}^{2+}$, in ascending hydrothermal solution, is capable of reducing $\mathrm{Mn}^{4+}$; this is therefore a possible mechanism both for reducing and remobilizing the $\mathrm{Mn}$ crusts and at the same time for oxidizing $\mathrm{Fe}^{2+}$ in ascending hydrothermal solutions to $\mathrm{Fe}^{3+}$, in which form it can precipitate out in nontronite. This process has been suggested by Honnorez, Von Herzen et al. (1981) as a possible mechanism of mounds formation. While Mn oxides have been reported as being extensive in the mounds field (Corliss et al., 1978; Williams et al., 1979), only small amounts were recovered on Leg 70 except at Hole 509B. This may be because during the recycling of $\mathrm{Mn}$ discussed above, not all the $\mathrm{Mn}$ is reprecipitated, some being lost to overlying bottom waters. If nontronite precipitation is to continue in the absence of buried Mn-crust another oxidant for the $\mathrm{Fe}^{2+}$ will be needed. Since the nontronite is highly granular, it is possible that mounds showing appreciable topography could entrain some oxygenated bottom water, and this would enable nontronite precipitation to continue even in the absence of buried Mn crust.

The buried nature of the Mn-oxide crusts and the interfingering of the nontronite and pelagic ooze seen in the mounds holes suggests that hydrothermal circulation in the mounds may be episodic in nature and that periods of normal pelagic sedimentation may be interspersed with pulses of hydrothermal activity which remobilize buried Mn crust and precipitate nontronite in 
the mounds interior. This process is similar to that proposed by Williams et al. (1979), although these authors suggest that the process may be continuous.

Whatever the mechanism of precipitation of the deposits, the nontronite is characterized by a very uniform chemical composition, both with depth within single mounds and between widely spaced mounds. This indicates that the fluids from which they are formed originate from a single large source which feeds the entire mounds field. The compositional variations which occur in the Mn crusts may be a result of mobilization and redeposition after their initial precipitation.

\section{REFERENCES}

Bischoff, J. L., and Rosenbauer, R. J., 1977. Recent metalliferous sediment in the North Pacific manganese nodule area. Earth Planet. Sci. Lett., 33:379-388.

Bonatti, E., Fisher, D. E., Joensuu, O., and Rydell, H. S., 1971. Postdepositional mobility of some transitional elements: $\mathrm{P}, \mathrm{U}$, and $\mathrm{Th}$ in deep-sea sediments. Geochim. Cosmochim. Acta, 35:189-201.

Bonatti, E., Kraemer, T., and Rydell, H. S., 1972. Classification and genesis of submarine iron-manganese deposits. In Horn, D. R. (Ed.), Papers from a Conference on Ferromanganese Deposits on the Ocean Floor: Washington (National Science Foundation), pp. 149-165.

Boström, K., Joensuu, O., Valdes, S., Charm, W., and Glaccum, R., 1976. Geochemistry and origin of East Pacific sediments sampled during DSDP Leg 34. In Yeats, R. S., Hart, S. R., et al., Init. Repts. DSDP, 34: Washington (U.S. Govt. Printing Office), 559-574.

Calvert, S. E., 1974. Deposition and diagenesis of silica in marine sediments. Spec. Publ. Int. Assoc. Sedimentol., 1:273-299.

Cann, J. R., Winter, C. K., and Pritchard, R. G., 1977. A hydrothermal deposit from the floor of the Gulf of Aden. Min. Mag., 41:193-199.

Chester, R., and Aston, S. R., 1976. The geochemistry of deep-sea sediments. In Riley, J. P., and Chester, R. (Eds.), Chemical Oceanography (Vol. 6): New York (Wiley Interscience), 281-391.

Corliss, J. B., Lyle, M., Dymond, J., and Crane, K., 1978. The chemistry of hydrothermal mounds near the Galapagos Rift. Earth Planet. Sci. Lett., 40:12-24.

Cronan, D. S., 1972. Regional geochemistry of ferromanganese nodules from the world ocean. In Horn, D. R. (Ed.), Papers from a Conference on Ferromanganese Deposits on the Ocean Floor: Washington, D.C. (National Science Foundation), pp. 19-30. 1975. Manganese nodules and other ferromanganese oxide deposits. In Riley, J. P., and Chester, R. (Eds.), Chemical Oceanography (Vol. 5): New York (Wiley Interscience), 217-263. 1976. Basal metalliferous sediments from the eastern Pacific. Bull. Geol. Soc. Am., 87:928-934.

Dapples, E. C., 1967. Silica as an agent in diagenesis. In Larson, G., and Chilingar, G. V. (Eds.), Developments in Sedimentology (Vol. 8): New York (Elsevier), 323-342.

Donnelly, T. W., 1980. Secondarily modified sediments of the eastern Pacific: Major element chemistry of Sites 420,424 , and 425 , DSDP Leg 54. In Rosendahl, B. R., Hekinian, R., et al., Init. Repts. DSDP, 54: Washington (U.S. Govt. Printing Office), 329-338.

Dymond, J., Corliss, J. B., Cobler, R., Muratli, C. M., Chou, C., and Conrad, R., 1980. Composition and origin of sediments recovered by deep drilling of sediment mounds, Galapagos Spreading Center. In Rosendahl, B. R., Hekinian, R., et al., Init. Repts. DSDP, 54: Washington (U.S. Govt. Printing Office), 377-386.

Dymond, J., Corliss, J. B., Heath, G. R., Field, C. W., Dasch, E. J., and Veeh, H., 1973. Origin of metalliferous sediments from the Pacific Ocean. Bull. Geol. Soc. Am., 84:3355-3372.
Froehlich, P. N., Bender, M. L., and Heath, G. R., 1977. Phosphorus accumulation rates in metalliferous sediments on the East Pacific Rise. Earth Planet. Sci. Lett., 34:351-359.

Harder, H., 1976. Nontronite synthesis at low temperatures. Chem. Geol., 18:169-180.

Heath, G. R., and Dymond, J., 1977. Genesis and transformation of metalliferous sediments from the East Pacific Rise, Bauer Deep and Central Basin, Northwest Nazca Plate. Bull. Geol. Soc. Am., 88:723-733.

Hekinian, R., Rosendahl, B. R., Cronan, D. S., Dmitriev, Y., Fodor, R. V., Goll, R. M., Hoffert, M., Humphris, S. E., Mattey, D. P., Natland, J., Petersen, N., Roggenthen, W., Schrader, E. L., Srivastava, R. K., and Warren, N., 1978. Hydrothermal deposits and associated basement rocks from the Galapagos Spreading Centre. Oceanol. Acta, 1:473-482.

Hoffert, M. Person, A., Curtois, C., Karpoff, A. M., and Trauth, D., 1980. Sedimentology, mineralogy and geochemistry of hydrothermal deposits from Holes 424, 424A, 424B, and 424C (Galapagos Spreading Center). In Rosendahl, B. R., Hekinian, R., et al., Init. Repts. DSDP, 54: Washington (U.S. Govt. Printing Office), 339-376.

Honnorez, J., Von Herzen, R. P., Barrett, T., Becker, K., Bender, M., Borella, P., Hubberten, H.-W., Jones, S., Karato, S., Laverne, C., Levi, S., Migdisov, A., Moorby, S. A., and Schrader, E. L., 1981. Hydrothermal mounds and young ocean crust of the Galapagos: Preliminary Deep Sea Drilling results, Leg 70. Bull. Geol. Soc. Am., Pt. I, 92:457-472.

Klitgord, K. D., and Mudie, J. D., 1974. The Galapagos Spreading Centre. A near bottom geophysical survey. Geophys. J. R. Astron. Soc., 38:563-586.

Lynn, D., and Bonnatti, E., 1965. Mobility of manganese in diagenesis of deep-sea sediments. Mar. Geol., 3:457-474.

Mattey, D. P., and Muir, I. D., 1980. Geochemistry and mineralogy of basalts from the Galapagos Spreading Center. In Rosendahl, B. R., Hekinian, R., et al., Init. Repts. DSDP, 54: Washington (U.S. Govt. Printing Office), 755-772.

Natland, J. H., Rosendahl, B. R., Hekinian, R., Dmitriev, Y., Fodor, R. V., Goll, R. M., Hoffert, M., Humphris, S. E., Mattey, D. P., Petersen, N., Roggenthen, W., Schrader, E. L., Srivastava, R. K., and Warren, N., 1979. Galapagos hydrothermal mounds: Stratigraphy and chemistry revealed by deep-sea drilling. Science, 204: 613-616.

Pedro, G., Carmouze, J. P., and Velde, B., 1978. Peloidal nontronite formation in recent sediments of Lake Chad. Chem. Geol., 23: 139-149.

Schrader, E. L., Furbish, W. J., Mattey, D., and May, J. A., 1980a. Geochemistry and carbonate petrology of selected sediment samples from DSDP Leg 54, Eastern Pacific. In Rosendahl, B. R., Hekinian, R., et al., Init. Repts. DSDP, 54: Washington (U.S. Govt. Printing Office), 319-328.

Schrader, E. L., Rosendahl, B. R., Furbish, W. J., and Mattey, D. P., $1980 \mathrm{~b}$. Mineralogy and geochemistry of hydrothermal and pelagic sediments from the mounds hydrothermal field, Galapagos Spreading Center: DSDP Leg 54. J. Sed. Pet., 50:917-928.

Scott, M. R., Scott, R. B., Rona, P. A., Butler, L. W., and Nalwalk, A. J., 1974. Rapidly accumulating manganese deposit from the median valley of the mid-Atlantic Ridge. Geophys. Res. Lett., $1: 355-359$.

Seyfried, W., and Bischoff, J. L., 1977. Hydrothermal transport of heavy metals by seawater: The role of the seawater/basalt ratio. Earth Planet. Sci. Lett., 34:71-77.

Toth, J. R., 1980. Deposition of submarine crusts rich in manganese and iron. Bull. Geol. Soc. Am., 91:44-54.

Williams, D. L., Green, K., van Andel, Tj. H., Von Herzen, R. P., Dymond, J. R., and Crane, K., 1979. The hydrothermal mounds of the Galapagos Rift: Observations with DSRV "ALVIN" and detailed heat-flow studies. J. Geophys. Res., 84:7467-7484. 